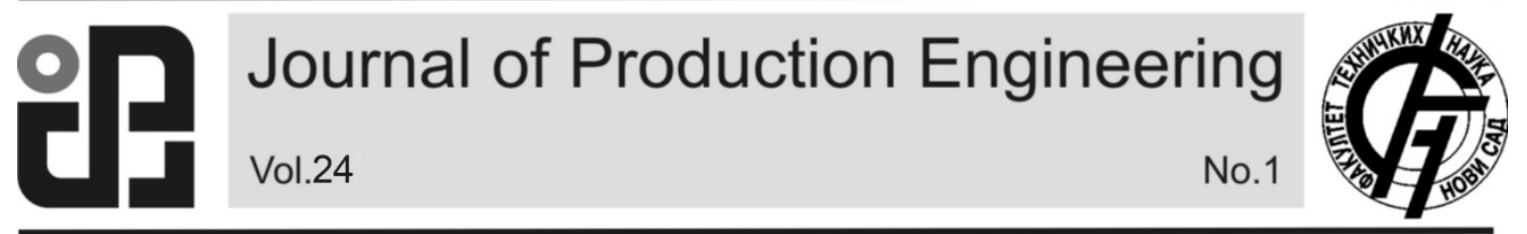

JPE (2021) Vol.24 (1)

Bányai, Á.

Original Scientific Paper

\title{
EXCHANGE CURVE-BASED INVENTORY POLICY ANALYSIS OF NON-REUSABLE INDUSTRIAL PACKAGING IN PRODUCTION
}

Received: 07 March 2021 / Accepted: 13 June 2021

\begin{abstract}
The well-chosen inventory policy has a great impact on the performance of production and logistics processes, because it can influence not only the reliability, the cost efficiency, and the sustainability of the processes and resources, but packaging system can force the quality of products and processes. Within the frame of this article an exchange curve-based analysis method of packaging related inventory policy is described. This analysis method makes it possible to highlight the problems in inventory policy and find an improve solution in both macro- and micro-level. The computation method is based on the exchange of annual order cost and average inventory investment, especially in the case of economic order quantity-based packaging order policies.
\end{abstract}

Keywords: Annual order cost, average inventory investment, inventory policy, packaging logistics, procurement.

Analiza politike zaliha zasnovane na krivoj razmene industrijske ambalaže koja se ne može ponovo koristiti u proizvodnji. Dobro izabrana politika inventara ima veliki uticaj na performanse proizvodnih i logističkih procesa, jer može uticati ne samo na pouzdanost, ekonomičnost i održivost procesa i resursa, već sistem pakovanja može forsirati kvalitet proizvoda i procesa. U okviru ovog članka opisana je metoda analize zasnovana na krivoj razmene politike zaliha u vezi sa ambalažom. Ova metoda analize omogućava isticanje problema $u$ politici zaliha $i$ pronalaženje poboljšanog rešenja i na makro i na mikro nivou. Metoda izračunavanja zasniva se na razmeni godišnjih troškova narudžbine $i$ prosečnih ulaganja u zalihe, posebno u slučaju politika naručivanja ambalaže zasnovane na količini ekonomske porudžbine.

Ključne reči: Godišnji trošak narudžbine, prosečno ulaganje u zalihe, politika zaliha, logistika ambalaže, nabavka.

\section{INTRODUCTION}

The optimization of inventory control policies plays an important role in the life of both production and service companies. It is especially true in the case of packaging logistics, because packaging logistics has a great impact of the whole value chain including procurement, production, distribution and inverse processes.

However, FMCG (fast moving consumer goods) or CPG (consumer packaged goods) producers use the JIT (just-in-time) or JIS (just-in-sequence) philosophy for the procurement of packaging, but in a wide range of production and service operations, the standard inventory policies, like economic order quantity are also suitable tools. The inventory management problems and inventory policies focus on a wide range of design and optimization problems, including planned and nonplanned shortages [1], safety stocks [2], inventory availability, economic and ecological aspects [3].

This paper is organized as follows. Section 2 describes a short systematic literature review focusing on the research results in the field of decision making and optimisation in packaging logistics. Section 3 describes the model framework of exchange curvebased decision support system to optimise inventory policy of packaging for production processes. Section 4 presents computational results of the described exchange curve-based analysis including macro- and micro-level decisions. Conclusions, results and future research directions are discussed in the last section.

\section{LITERATURE REVIEW}

As the Smithers statistics shows [4], the industrial packaging market will increase from 56.2 billion USD in 2019 to 66.0 billion USD in 2024 with an annual growing rate of $3.3 \%$. This rate shows the importance of industrial packaging logistics both from economic and ecological point of view. This economic and ecological importance has indicated scientific research works focusing on a wide range of packaging related topics including packaging design, packaging materials, network design, and packaging logistics. These multidisciplinary research topics makes it necessary to make a short systematic literature review to show the main research directions and research results. Within the frame of the short systematic literature review the main research gaps are identified. I have used the "packaging logistics" keyword to search in the ScienceDirect database. Initially, 117 articles were identified. The search was conducted in June 2021; therefore, new articles may have been published since then. The descriptive analysis shows, that packaging logistics is extensively researched in the past five years. The first article regarding the role of the packaging logistics was published in 1994 focusing on the importance of partnership in supply chain. In the next years, various topics were aimed, and a wide range of research results were published focusing on the theoretical and practical aspects of packaging related problems. One of the most important topics is the application of Industry 4.0 technologies in the packaging industry. 
Industry 4.0 offers new directions for the improvement of packaging logistics processes including a wide range of new technologies, like cloud, fog and edge computing to support the solutions of big data problems, the application of smart sensors and microsensors to increase the safety of packaged products in the case of both consumer and industrial packaging. Within the frame of this short literature review we are analysing both industrial and consumer packaging related researches. The number of published articles (see Figure 1) has been extensively increased in the last five years and this fact shows the importance of packaging logistics. The distribution of article types shows (Figure 2), that not only research article, but also book chapters, short communications were written by the authors. The distribution of sources (Figure 3) and subject areas (Figure 4) validate, that packaging logistics is a multidisciplinary science, it can integrate sciences, like environmental sciences, agricultural sciences, energy, engineering, social sciences, business and management and decision sciences. The presented research work can be categorised as an integration of computer sciences, engineering and decision sciences, but business aspects are also integrated in this research work.

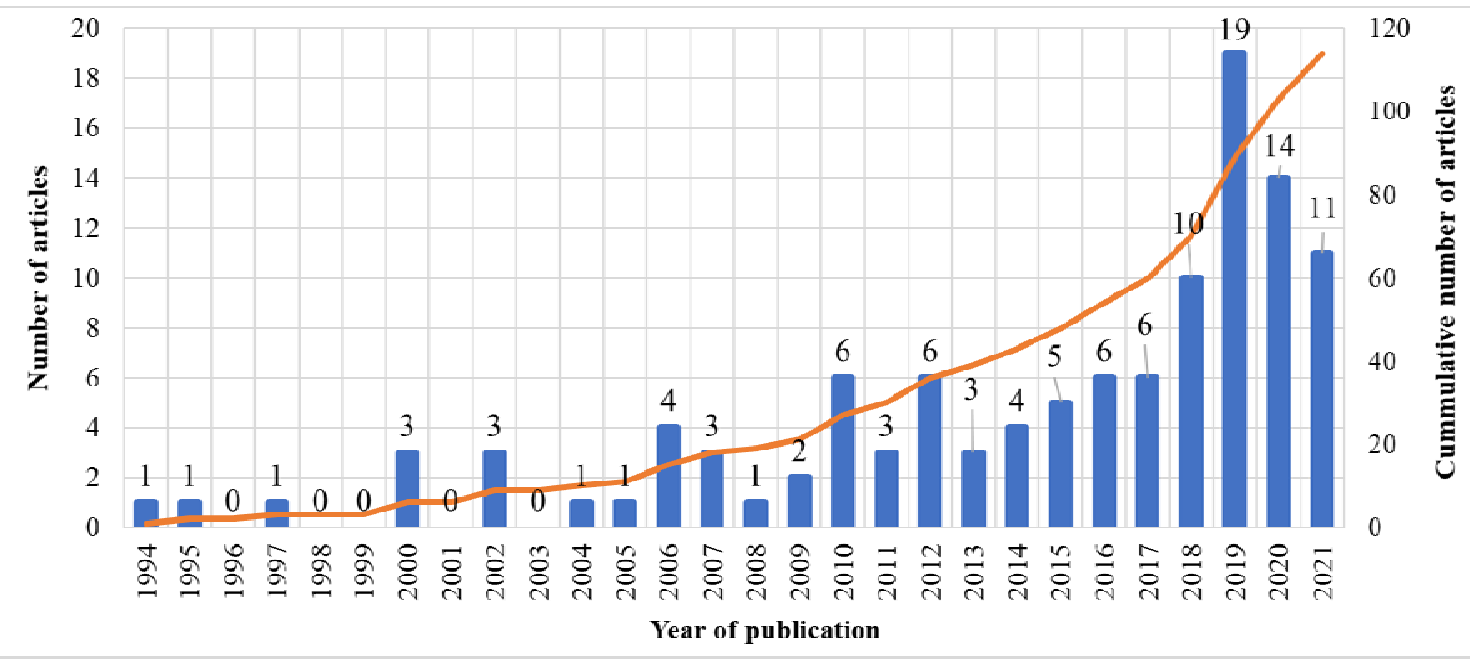

Fig. 1. Yearly distribution of articles based on ScienceDirect search.

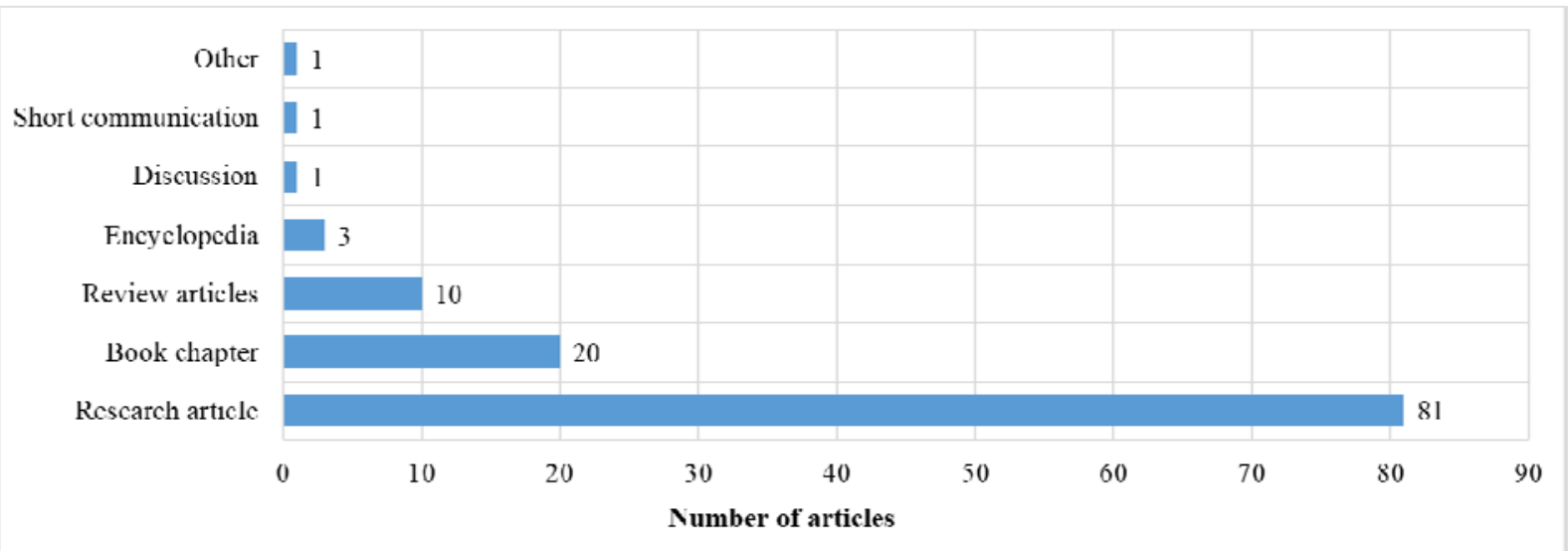

Fig. 2. Distribution of article types based on ScienceDirect search.

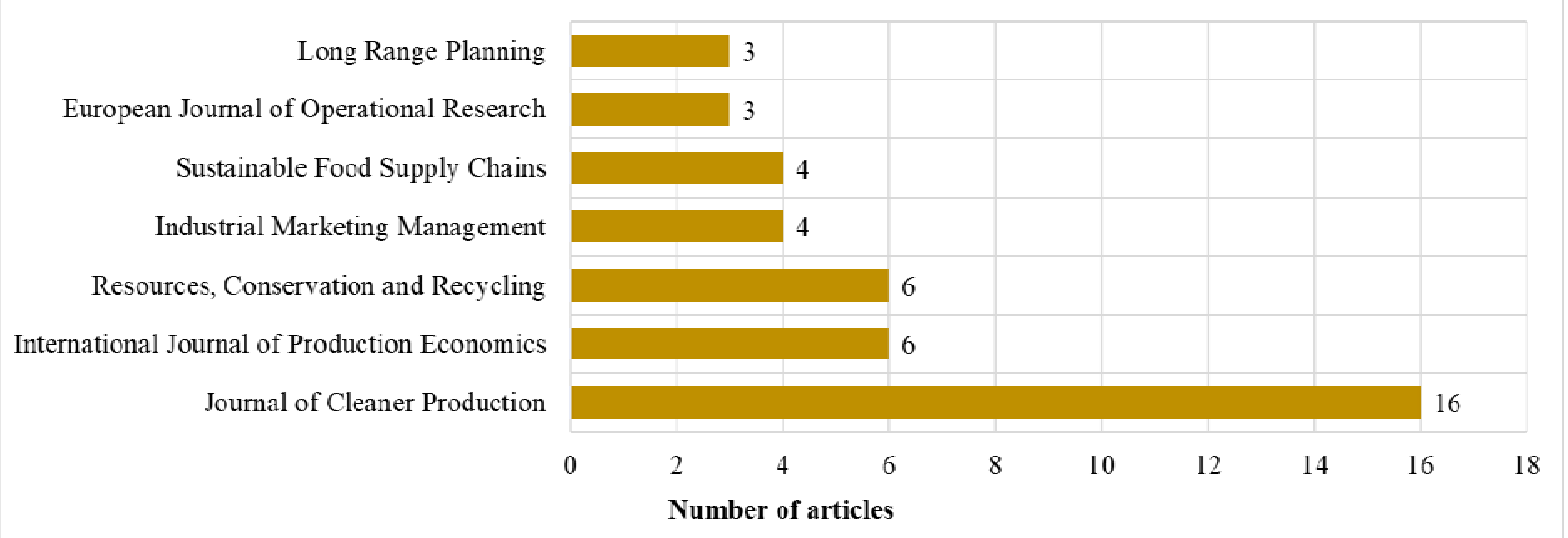

Fig. 3. Distribution of sources (publication titles) based on ScienceDirect search. 


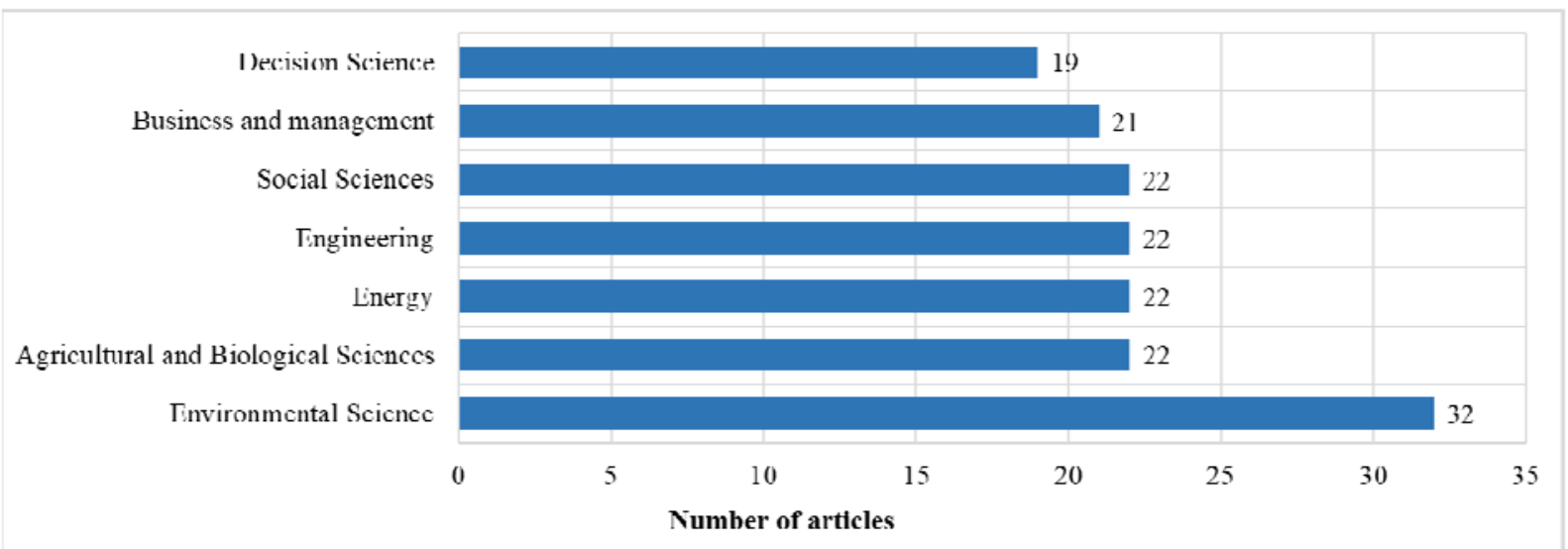

Fig. 4. Distribution of subject areas based on ScienceDirect search.

One critical sector of production processes is the optimal design and operation of reverse logistics operations in circular economy, especially from reusable packaging point of view. There is a wide range of challenges regarding design and operation, for example, the use of reusable semi-finished product shipping boxes and packaging in the case of LCD production [5]. The fresh food supply chains with reusable and disposable packaging containers can be optimized based on a bi-objective optimization model, where both costs and environmental aspects are taken into consideration. Using a mixed integer linear programming model, it is possible to support the decision making regarding packaging container selection, storage and handling node location and flow allocation [6].

The environmental aspects of packaging solutions are analysed in many segments of production and service, like furniture industry [7], self-service kiosks [8], and the results shows, that the sustainable packaging strategy is a key factor for an environmentally-friendly value chain. The conventional packaging scorecards are today not suitable within the frame of the circular economy, therefore new, special packaging scorecards were developed in France for circular economy [9].

The transformation between exploration and exploitation applied to inventors of packaging innovations is a core research task not only from product development but also from packaging logistics point of view, because innovation in packaging design has a great impact on the performance of packaging logistics and supply chain solutions regarding both economic and ecological aspects. The conceptknowledge theory offers a suitable framework to answer the main innovation-related questions of packaging design, because this theory offers a comprehensive formalization of packaging design and explains invention, creation, and discovery [10].

The performance and sustainability of city logistics is influenced by the packaging logistics. The profitable city logistics initiatives are based on a wide range of core competences, including Industry 4.0 technologies, consolidation of transportation of goods and up-to-date packaging technologies and processes [11].

The digitalisation of conventional supply chain solutions and the transformation of conventional production and service systems into cyber-physical systems has a great impact on packaging logistics $[12,13]$. Not only cost efficiency, but also sustainable aspects, like energy consumption has to be analysed in the case of different value chains based on e-commerce or conventional trade channels, because packaging systems have special aspects in both cases [14].

Packaging logistics is especially important in the field of food industry. The complex value chain structure of the food industry is linking input suppliers to farmers, then farmers upstream to wholesalers and processors midstream, to retailers then consumers downstream. In this complex "link-chain" the cost effective, safe and sustainable packaging systems play an important role [15,16]. Other important food packaging-related research topics are the followings: sustainability governance and contested plastic food packaging [17]; e-commerce food packaging from resources, performance, and trends point of view [18]; food packaging's materials [19-22], food packaging permeability [23].

For the analysis of different control strategies of packaging systems, we can use both analytical, and heuristic methods or simulation. In the case of returnable transport items and containers, simulationbased scenario analysis shows the impact of different control strategies on the investments and operating costs and emphasizes, that the integration of a well-chosen control strategy and a suitable Industry 4.0 technologies (e.g. tracking system) can lead to a full control of returnable transport item shrinkage [24].

However, within the frame of this article the logistic aspects of packaging in value chains are analysed, but it is important to show, that a wide range of packaging related researches are focusing on other fields, like shelf-life variations in pallet unit loads during perishable food supply chain distribution [25], which emphasizes the importance of continuous temperature monitoring and shows the importance of intelligent sensor systems in packaging logistics.

About $50 \%$ of the articles were published in the last five years. This result indicates the scientific potential of the research of packaging logistics. The articles that addressed the development of packaging logistics are focusing on different fields of production and services, but only a few of them describe both macro- and microlevel decision support analytics of packaging 
procurement decisions. As a consequence, the main contributions of this article are the followings: (1) general model of decision support analysis based on the exchange curve including annual order cost and average inventory investment; (2) mathematical description of the potentials in exchange curve-based packaging regarding inventory policy analysis and improvement in macro- and micro-level; (3) computational results to validate the described model.

\section{EXCHANGE CURVE-BASED MODEL TO OPTIMISE INVENTORY POLICY}

The inventory policy of packaging can be optimised in many ways. In generally, the inventory policy of packaging is based on the theory of economic order quantity, therefore within the frame of this model we take into consideration the EOQ strategy for inventory control, which is a generally used inventory policy [2629]. We can define the average inventory investment (AII) as follows:

$$
A I I=\sum_{i=1}^{m} \frac{q_{i}}{2} \cdot c_{i} .
$$

where $c_{i}$ is the specific purchasing cost of packaging $\mathrm{i}$, $q_{i}$ is the economic order quantity, which can be calculated:

$$
q_{i}=\sqrt{\frac{2 \cdot Q_{i} \cdot c_{i}^{O}}{c_{i}^{P} \cdot c^{W}}}
$$

where $Q_{i}$ is the annual demand of packaging i, $c_{i}^{O}$ is the specific order cost of packaging $\mathrm{i}, c_{i}^{P}$ specific purchasing cost, $c^{W}$ is the specific warehousing cost of packaging.

Using the economic order quantity for all packaging the average inventory investment can be calculated:

$$
A I I=\frac{1}{2} \cdot \sum_{i=1}^{m} c_{i}^{P} \cdot \sqrt{\frac{2 \cdot Q_{i} \cdot c_{i}^{O}}{c_{i}^{P} \cdot c^{W}}},
$$

and

$$
A I I=\frac{1}{\sqrt{2 \cdot c^{W}}} \cdot \sum_{i=1}^{m} \sqrt{Q_{i} \cdot c_{i}^{O} \cdot c_{i}^{P}} .
$$

The annual order cost (AOC) can be calculated in the same way:

$$
A O C=\sum_{i=1}^{m} \frac{Q_{i} \cdot c_{i}^{O}}{q_{i}} .
$$

Using the economic order quantity for all packaging the annual order cost can be calculated:

and

$$
A O C=\sum_{i=1}^{m} Q_{i} \cdot c_{i}^{O} \cdot \sqrt{\frac{c_{i}^{P} \cdot c^{W}}{2 \cdot Q_{i} \cdot c_{i}^{O}}} .
$$

$$
A O C=\sqrt{\frac{c^{W}}{2}} \cdot \sum_{i=1}^{m} \sqrt{Q_{i} \cdot c_{i}^{O} \cdot c_{i}^{P}} .
$$

Based on the values of the average inventory investment and the annual order cost we can draw an exchange curve, which is a plot between these values.

We can define the optimal inventory policy based on the AOC-AII plot, because the trade-off between warehousing and purchasing must be defined so, that the total investment in inventory has to be minimized, while the number of annual order has to be taken into consideration as a constraint of the inventory strategy optimisation. If the investment in inventories is defined, then we have to minimize the annual order cost to optimize inventory policy [30]. It means, that we transform either investment of inventory into annual order cost or vice versa, which means, that the multiplication of investment of inventory and annual order cost is a constant value.

$$
A I I \cdot A O C=\frac{1}{2} \cdot\left\{\sum_{i=1}^{m} c_{i}^{P} \cdot \sqrt{Q_{i} \cdot c_{i}^{O} \cdot c_{i}^{P}}\right\}^{2}
$$

This rectangular hyperbola is the exchange curve which is shown in Figure 5. The AOC-AII plot is a rectangular hyperbola, because its axes are perpendicular.

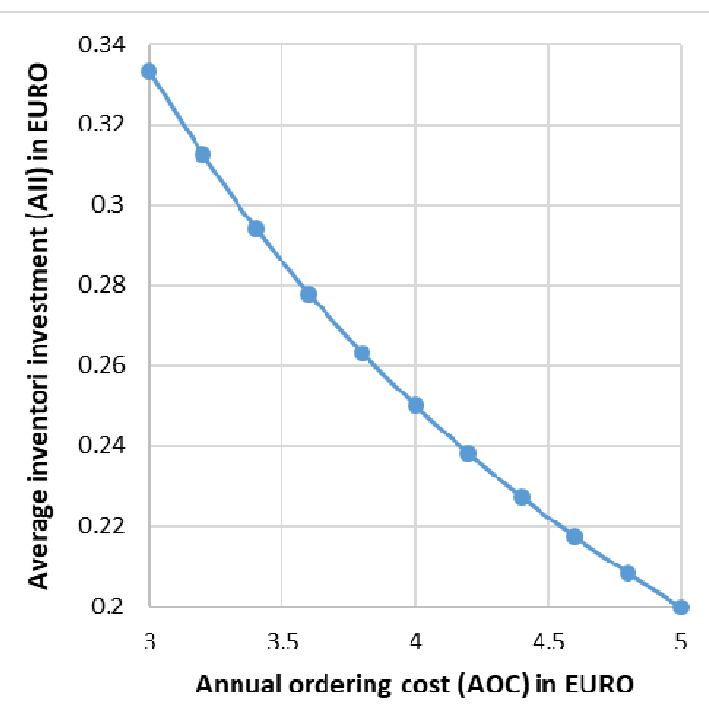

Fig. 5. Exchange curve (AOC-AII plot) as a rectangular hyperbola.

Based on the exchange curve we can analyse an existing inventory policy and we can define a better investment strategy for a chosen set of packaging. As Figure 6 shows, $\alpha-\beta$ means that annual ordering cost can be decreased while inventory investment is constant and $\alpha-\gamma$ means that inventory investment can be decreased while annual ordering cost is constant. With other words, $\alpha-\beta$ means that we reduce the number of annual orders, while $\alpha-\gamma$ means that we reduce the inventory.

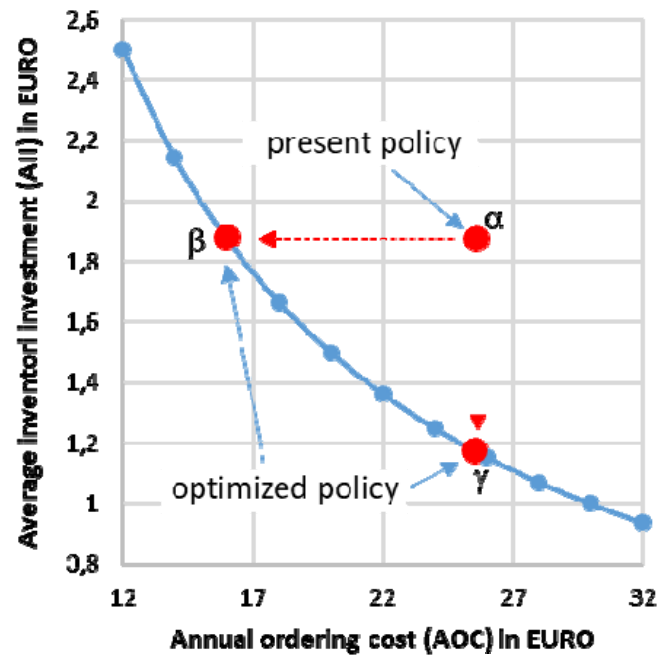

Fig. 6. Potential paths to optimize present inventory policy. 
Another application field of the exchange curve is to find the optimal inventory policy if the annual ordering cost or the average inventory investment is limited. Figure 7. shows a numerical example for the decision support function of the exchange curve. If the annual ordering cost of packaging is limited to 2500 EURO, then the optimal inventory policy is to choose point $\alpha$ on the exchange curve, and in this case the average inventory investment is 1200 EURO.

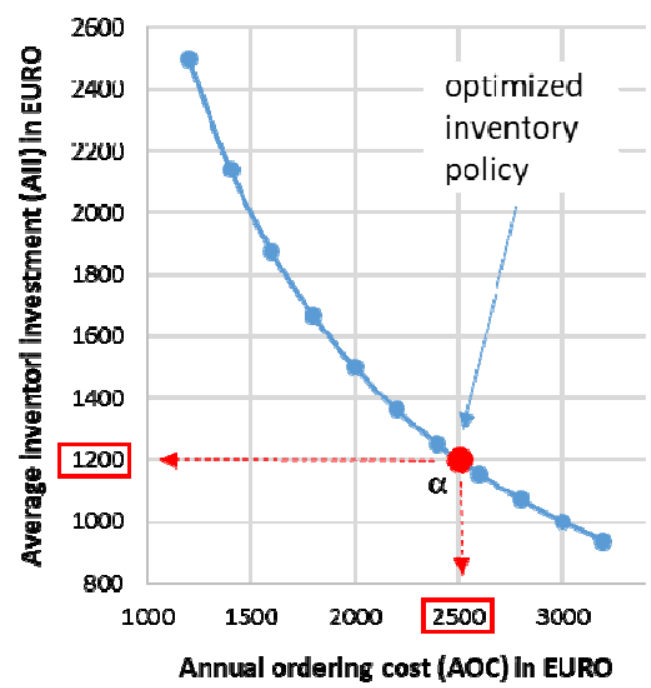

Fig. 7. Numerical example for the exchange of annual ordering cost and average inventory investment, while annual ordering cost is limited.

\section{COMPUTATIONAL RESULTS}

Within the frame of this chapter, the application potential of exchange curve in inventory policy analysis is demonstrated. Within the frame of the Scenario 1, the packaging order policy is analysed, where the annual demand of packaging, the specific order cost of packaging and the specific purchasing cost are given in all seven packaging types (P01-P07) (see Table 1). The company orders the packaging 30 times yearly and the annual order cost of this solution is 10050 EURO, while the average inventory investment is 79633 EURO (see equations (1) and (5)).

\begin{tabular}{|c|c|c|c|}
\hline Packaging ID & $\begin{array}{c}c_{i}^{O} \\
{[€ / \text { order] }}\end{array}$ & $\begin{array}{c}Q_{i} \\
\text { [pcs/year] }\end{array}$ & $\begin{array}{c}c_{i}^{P} \\
{[€ / \text { pcs] }}\end{array}$ \\
\hline P01 & 150 & 5600 & 25 \\
\hline P02 & 20 & 8200 & 45 \\
\hline P03 & 50 & 5000 & 90 \\
\hline P04 & 120 & 15000 & 70 \\
\hline P05 & 12 & 12000 & 20 \\
\hline P06 & 50 & 30000 & 30 \\
\hline P07 & 20 & 4000 & 55 \\
\hline
\end{tabular}

Table 1. Input parameters of the Scenario.

Based on equations (1-8) we can calculate the annual order cost and the value of average inventory investment depending on the value of specific warehousing cost, as shown in Table 2. As Figure 8 shows, there are two ways to improve the present inventory strategy represented by the point $\alpha$. In the case of 30 annual orders the annual order cost is 10050
EURO (see $\alpha$ in Figure 8), but it is possible to find a same annual order cost on the exchange curve (see $\gamma$ in Figure 8), where the average inventory investment of packaging is smaller, therefore there total sum is smaller with 22895 EURO.

\begin{tabular}{|c|c|c|}
\hline $\begin{array}{c}c^{W} \\
{[€ / \text { year }]}\end{array}$ & $\begin{array}{c}A O C \\
{[€]}\end{array}$ & $\begin{array}{c}A I I \\
{[€]}\end{array}$ \\
\hline 0.01 & 2387.93 & 238793.20 \\
\hline 0.05 & 5339.58 & 106791.56 \\
\hline 0.09 & 7163.80 & 79597.73 \\
\hline 0.13 & 8609.81 & 66229.32 \\
\hline 0.17 & 9845.70 & 57915.86 \\
\hline 0.21 & 10942.88 & 52108.95 \\
\hline 0.25 & 11939.66 & 47758.64 \\
\hline 0.29 & 12859.41 & 44342.78 \\
\hline 0.33 & 13717.62 & 41568.56 \\
\hline 0.37 & 14525.22 & 39257.36 \\
\hline 0.41 & 15290.23 & 37293.23 \\
\hline 0.45 & 16018.73 & 35597.19 \\
\hline 0.49 & 16715.52 & 34113.31 \\
\hline 0.53 & 17384.41 & 32800.77 \\
\hline 0.57 & 18028.49 & 31628.93 \\
\hline 0.61 & 18650.34 & 30574.34 \\
\hline 0.65 & 19252.12 & 29618.65 \\
\hline 0.69 & 19835.65 & 28747.32 \\
\hline 0.73 & 20402.50 & 27948.63 \\
\hline 0.77 & 20954.02 & 27213.01 \\
\hline 0.81 & 21491.39 & 26532.58 \\
\hline 0.85 & 22015.64 & 25900.76 \\
\hline 0.89 & 22527.71 & 25312.03 \\
\hline
\end{tabular}

Table 2. Computational results of the average inventory investment and annual ordering cost in the Scenario.

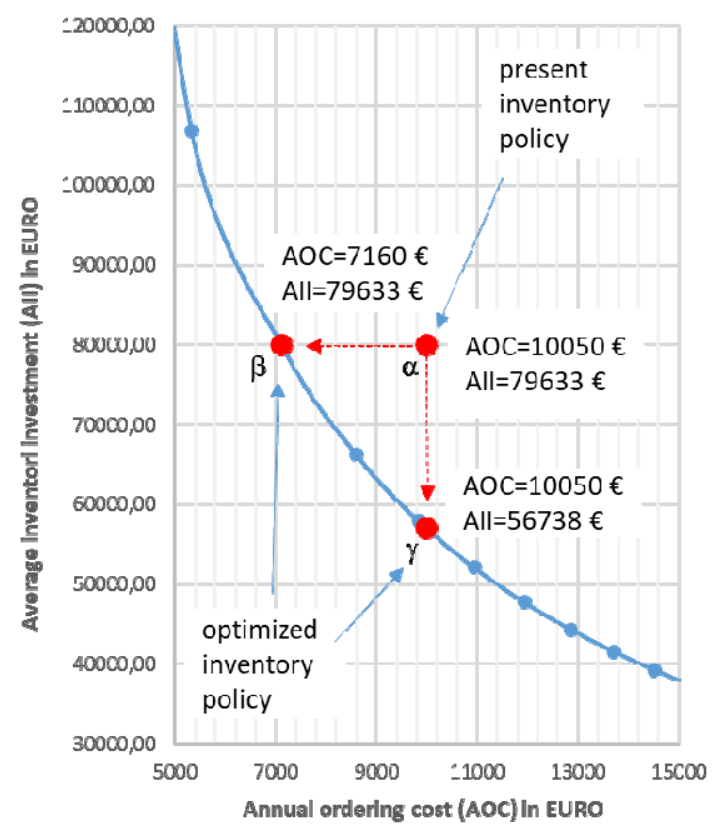

Fig. 8. Computational results of the Scenario: the present inventory policy can be changed in two directions: $\alpha-\beta$ means that we reduce the number of annual orders, while the average inventory investment is constant; $\alpha-\gamma$ means that we reduce the inventory investment, while the annual ordering cost is constant. 
Another way is to fix the average inventory investment and find a smaller annual order cost, which also means a changed inventory policy with less than 30 orders. This way results 2890 EURO saving in annual order cost. In the case of both ways, we can define a new inventory policy in macro-level. Macro-level means, that exchange curve can highlight bottlenecks, but after that, we have to find the new inventory policy on micro-level using the economic order quantity, as equation (2) shows.

The first step of the micro-level optimization of the packaging inventory policy is the computation of ${ }_{c}{ }^{W}$ belonging to the $\beta$ or $\gamma$ solution. Each point of the exchange curve represents an individual $c^{W}$ value, which can be calculated and after that we can define the optimal inventory policy for each packaging on microlevel. For the $\gamma$ solution we can calculate the value of ${ }^{W}$ in the following way:

$$
\begin{gathered}
\operatorname{AOC}(\alpha)=\operatorname{AOC}(\gamma), \\
c^{W}(\gamma)=\frac{2 \cdot\{\operatorname{AOC}(\alpha)\}^{2}}{\left\{\sum_{i=1}^{m} \sqrt{Q_{i} \cdot c_{i}^{O} \cdot c_{i}^{P}}\right\}^{2}} .
\end{gathered}
$$

In the same way we can calculate the $c^{W}$ value for the $\beta$ solution:

$$
\begin{gathered}
A I I(\alpha)=A I I(\beta), \\
c^{W}(\beta)=\frac{1}{2} \cdot \frac{\left\{\sum_{i=1}^{m} \sqrt{Q_{i} \cdot c_{i}^{O} \cdot c_{i}^{P}}\right\}^{2}}{\{A I I(\alpha)\}^{2}} .
\end{gathered}
$$

Based on equation (8) we can simplify equations (9-12) as follows:

$$
\frac{A O C(\beta)}{A I I(\beta)}=c^{W}(\beta) \text { and } \frac{A O C(\gamma)}{A I I(\gamma)}=c^{W}(\gamma)
$$

and

$$
c^{W}(\beta)=0.0899 \text { and } c^{W}(\gamma)=0.1771
$$

\begin{tabular}{|c|c|c|c|}
\hline Packaging ID & $\begin{array}{c}t c \\
\text { [day] }\end{array}$ & $\begin{array}{c}A O C(\beta) \\
{[€]}\end{array}$ & $\begin{array}{c}A I I(\beta) \\
{[€]}\end{array}$ \\
\hline P01 & 9.39 & 971.57 & 10807.24 \\
\hline P02 & 28.51 & 575.96 & 6406.68 \\
\hline P03 & 32.66 & 1005.67 & 11186.55 \\
\hline $\mathrm{P} 04$ & 10.73 & 2379.85 & 26472.20 \\
\hline P05 & 20.29 & 359.80 & 4002.22 \\
\hline P06 & 7.69 & 1422.23 & 15820.21 \\
\hline P07 & 45.14 & 444.72 & 4946.88 \\
\hline
\end{tabular}

Based on the above calculation, we can define the optimal inventory policy on micro-level for both $\beta$ and $\gamma$ solution (see Table 3 and 4), where $t c$ is the cycle

\begin{tabular}{|c|c|c|c|}
\hline Packaging ID & $\begin{array}{c}t c \\
\text { [day] }\end{array}$ & $\begin{array}{c}A O C(\gamma) \\
{[€]}\end{array}$ & $\begin{array}{c}A I I(\gamma) \\
{[€]}\end{array}$ \\
\hline P01 & 6.69 & 1363.65 & 7699.91 \\
\hline P02 & 20.31 & 808.39 & 4564.62 \\
\hline P03 & 23.27 & 1411.51 & 7970.16 \\
\hline P04 & 7.64 & 3340.25 & 18860.81 \\
\hline $\mathrm{P} 05$ & 14.45 & 504.99 & 2851.49 \\
\hline P06 & 5.48 & 1996.18 & 11271.52 \\
\hline P07 & 32.16 & 624.19 & 3524.54 \\
\hline
\end{tabular}
time of orders.

Table 3. Parameters of micro-level inventory policy of solution $\beta$ based on exchange curve-based computation.

Table 4. Parameters of micro-level inventory policy of solution $\gamma$ based on exchange curve-based computation.
As the above-described Scenario validated, the exchange curve is a suitable tool to support decision making and analysis of inventory policy. This method makes it possible to analyse the inventory policy of EOQ-based procurement processes, like the procurement of packaging for production processes. The exchange curve-based analysis support macro-level and micro-level decisions regarding the inventory policy.

\section{SUMMARY AND CONCLUSIONS}

The packaging logistics represents a special sector of production and service processes, especially in the Industry 4.0 era. The processes of packaging logistics have great impact on the efficiency and performance of procurement, production and distribution processes, therefore it is important to find optimal packaging logistics solutions for production and service processes. Within the frame of this article the author described a potential application of exchange curves for the analysis of inventory policies for packaging procurement processes. The described exchange curve-based method makes it possible to support decision making regarding inventory policies both on macro- and micro-level. Using the exchange curve-based model the management can identify the macro-level problems of existing inventory policy and based on the annual order cost and average inventory investment calculation it is possible to find optimized micro-level inventory decisions for each packaging to be ordered for the production process. The computational results validated the potential of exchange curve in inventory management. The method has managerial impacts, because it supports managerial decisions, especially on the tactical level of procurement processes. The future research directions of this topic includes the development of an exchange curve-based analysis for uncertain production environment, because uncertainties in production processes have great impact on the economic aspects of decision making in production and production-related services, like maintenance, packaging logistics, quality control [31]. Other potential research direction is to integrate exchange curve with other EOQ models including special constraints regarding quantity discount or priorities [32].

\section{REFERENCES}

[1] Korponai, J., Bányainé Tóth, Á., Illés, B.: Context of the inventory management expenses in the case of planned shortages, Engineering Management in Production and Services, 9(1), p.p. 26-35, 2017.

[2] Korponai, J., Bányainé Tóth, Á., Illés, B.: The effect of the safety stock on the occurrence probability of the stock shortage, Management and Production Engineering Review, 8(1), p.p. 69-77, 2017.

[3] Korponai, J., Bányainé Tóth, Á., Illés, B.: Sensibility analysis of the planned availability period and of the impact of the cost factors on total costs. Advanced Logistic Systems: Theory and Practice, 10(1), p.p. 1328, 2016.

[4] Smithers: The Future of Industrial Packaging to 2024. https://www.smithers.com/services/market- 
reports/packaging/industrial-packaging-to-2024. Accessed: 12/06/2021.

[5] Kuo, T.S., Chiu, M.-C., Chung, W.H., Yang T.I.: The circular economy of LCD panel shipping in a packaging logistics system, Resources, Conservation and Recycling, 149, p.p. 435-444, 2019.

[6] Bortolini, M., Galizia, F.G., Mora, C., Botti, L., Rosano, M.: Bi-objective design of fresh food supply chain networks with reusable and disposable packaging containers, Journal of Cleaner Production, 184, p.p. 375-388, 2018.

[7] Handfield, R.B., Walton, S.V., Seegers, L.K., Melnyk, S.A.: Green value chain practices in the furniture industry, Journal of Operations Management, 15(4), p.p. 293-315, 1997.

[8] Vakulenko, Y., Oghazi, P., Hellström, D.: Innovative framework for self-service kiosks: Integrating customer value knowledge, Journal of Innovation \& Knowledge, 4(4), p.p. 262-268, 2019.

[9] Fulconis, F., Philipp, B.: Packaging Scorecard for Closed-loop Logistics Systems: A Sustainable Development Perspective, Procedia - Social and Behavioral Sciences, 238, p.p. 19-28, 2018.

[10] Gobbo, J.A., Olsson, A.: The transformation between exploration and exploitation applied to inventors of packaging innovations, Technovation, 30(5-6), p.p. 322-331, 2010.

[11] Katsela, K., Pålsson, H.: Viable business models for city logistics: Exploring the cost structure and the economy of scale in a Swedish initiative, Research in Transportation Economics, 100857, 2020.

[12] Bányai, T.: Real-time decision making in first mile and last mile logistics: how smart scheduling affects energy efficiency of hyperconnected supply chain solutions, Energies, 11(7), 1833, 2018.

[13] Akkad, M.Z., Bányai, T.: Multi-objective approach for optimization of city logistics considering energy efficiency, Sustainability, 12(18), 7366, 2020.

[14] Pålsson, H., Pettersson, F., Hiselius, L.W.: Energy consumption in e-commerce versus conventional trade channels - Insights into packaging, the last mile, unsold products and product returns, Journal of Cleaner Production, 164, p.p. 765-778, 2017.

[15] Reardon, T., Echeverria, R., Berdegué, J., Minten, B., Liverpool-Tasie, S., Tschirley, D., Zilberman, D.: Rapid transformation of food systems in developing regions: Highlighting the role of agricultural research \& innovations, Agricultural Systems, 172, p.p. 47-59, 2019.

[16] Beckeman, M., Skjöldebrand, C.: Clusters/networks promote food innovations, Journal of Food Engineering, 79(4), p.p. 1418-1425, 2007.

[17] Sundqvist-Andberg, H., Åkerman, M.: Sustainability governance and contested plastic food packaging - An integrative review, Journal of Cleaner Production, 306, p.p. 127111, 2021.

[18] Spruit, D., Almenar, E.: First market study in ecommerce food packaging: Resources, performance, and trends, Food Packaging and Shelf Life, 29, 100698, 2021.

[19] Liu, Y., Ahmed, S., Sameen, D.E., Wang, Y., Lu, R., Dai, J., Li, S., Qin, W.: A review of cellulose and its derivatives in biopolymer-based for food packaging application, Trends in Food Science \& Technology, 112, p.p. 532-546, 2021.

[20] Park, S., Jeon, Y., Han, T., Kim, S., Gwon, Y., Kim,
J.: Nanoscale manufacturing as an enabling strategy for the design of smart food packaging systems, Food Packaging and Shelf Life, 26, 100570, 2020.

[21] Sharma, S., Barkauskaite, S., Jaiswal, A.K., Jaiswal, S.: Essential oils as additives in active food packaging, Food Chemistry, 343, 128403, 2021.

[22] Mendes, A.C., Pedersen, G.A.: Perspectives on sustainable food packaging:- is bio-based plastics a solution?, Trends in Food Science \& Technology, 112, p.p. 839-846, 2021

[23] Lentschat, M., Buche, P., Dibie-Barthelemy, J., Menut, L., Roche, M.: Food packaging permeability and composition dataset dedicated to text-mining, Data in Brief, 36, 107135, 2021.

[24] Hellström, D., Johansson, O.: The impact of control strategies on the management of returnable transport items, Transportation Research Part E: Logistics and Transportation Review, 46(6), p.p. 1128-1139, 2010.

[25] Göransson, M., Jevinger, Å., Nilsson, J.: Shelf-life variations in pallet unit loads during perishable food supply chain distribution, Food Control, 84. p.p. 552560, 2018.

[26] Mokhtari, H.: Economic order quantity for joint complementary and substitutable items, Mathematics and Computers in Simulation, 154, p.p. 34-47, 2018.

[27] Ventura, R., Samuel, S.: Optimization of fuel injection in GDI engine using economic order quantity and Lambert W function, Applied Thermal Engineering, 101, p.p. 112-120, 2016

[28] Zhou, Y., Chen, C., Li, C., Zhong, Y.: A synergic economic order quantity model with trade credit, shortages, imperfect quality and inspection errors, Applied Mathematical Modelling, 40(2), p.p. 10121028, 2016.

[29] Pasandideh, S.H.R., Niaki, S.T.A., Nia, A.R.: A genetic algorithm for vendor managed inventory control system of multi-product multi-constraint economic order quantity model, Expert Systems with Applications, 38(3), p.p. 2708-2716, 2011.

[30] Concept of exchange curve. https://www.vskills.in/certification/tutorial/exchangecurve-and-aggregate-inventory-planning/ Accessed: 02/05/2021

[31] Bányai, T.: Economic aspects of decision making in production processes with uncertain component quality. Inzinerine Ekonomika / Engineering Economics, 30(1), p.p. 4-13, 2019.

[32] Bányainé Tóth, Á., Illés, B., Zhumatayeva, G., Bányai, T., Tamás, P.: Impact of logistic processes on economic order quantity with quantity discount: an optimization approach, Asian Journal of Advanced Research and Reports, 10(4), p.p. 44-52, 2020.

Author: Associate Professor Ágota Bányainé Tóth PhD, University of Miskolc, Faculty of Mechanical Engineering and Informatics, Institute for Logistics, Miskolc-Egyetemváros, 3515 Miskolc, Hungary, Phone: +36 46 565-111.

E-mail: altagota@uni-miskolc.hu 